\title{
Approach to patients with secondary spontaneous pneumothorax: Our clinical experience
}

\section{Sekonder spontan pnömotorakslı hastalara yaklaşım: Klinik deneyimimiz}

\author{
Mehmet Akif Tezcan, İbrahim Ethem Özsoy
}

Department of Thoracic Surgery, Kayseri Health Practice and Research Center, University of Health Sciences, Kayseri, Turkey

Corresponding author: Mehmet Akif Tezcan, MD, Department of Thoracic Surgery, Kayseri Health Practice and Research Center, University of Health Sciences, Kayseri, Turkey

E-mail: mehmetakiftercan@gmail.com

Received/Accepted: January 20, 2021 /March 02, 2021

Conflict of interest: There is not a conflict of interest.

\section{SUMMARY}

Objective: In this study, our aim is to analyze the etiological causes and treatment methods of patients with secondary spontaneous pneumothorax treated in our hospital.

Method: We retrospectively evaluated the data of 152 patients who were treated for Secondary spontaneous pneumothorax between January 2013 December 2017. All patients diagnosed with SSP were included in the study. The patients were examined in terms of age, gender, current lung disease, smoking, symptoms, imaging findings, localization of pneumothorax, pneumothorax rate, treatment methods, surgical indications, length of hospitalisation and mortality rate.

Results: One hundred and twenty eight $(84.2 \%)$ of 152 patients were men, 24 were women $(15.8 \%)$ and their mean age was $66 \pm 12.4$ (45-98). The most common symptoms were dyspnoea in 114 (75\%) patients, chest pain in $85(55.9 \%)$ patients and cough in $26(17.1 \%)$ patients. The most common comorbid pathology was Chronic obstructive pulmonary disease (COPD) in $39.5 \%$ patients. Tube thoracostomy was performed in $6(40 \%)$ of $15(9.9 \%)$ patients who were monitored with oxygen therapy. While $112(73.7 \%)$ patients were treated with tube thoracostomy only, $36(32.1 \%)$ of them who were inoperable were treated with pleurodesis by tube thoracostomy. Thirty one $(20.4 \%)$ patients were treated surgically, of which video-assisted thoracoscopic was performed in 17 (54.8\%) and thoracotomy in $14(45.2 \%)$. The majority of our surgical indications were prolonged air leak and recurrent pneumothorax.

Conclusions: Despite the great advances in surgical techniques in thoracic surgery in recent years, a standard treatment protocol has not been established in the treatment of SSP. While pneumothorax can be treated with only chest tube and/or pleurodesis in most patients, morbidity and mortality may increase with surgical treatment. Therefore, surgical treatment should be avoided as much as possible.

Keywords: Pleurodesis, spontaneous pneumothorax, tube thoracostomy.
ORCID IDs of the authors: M.A.T. 0000-0002-2642-187X İ.E.Ö. 0000-0003-2722-5309 
Yöntem: Ocak 2013-Aralık 2017 tarihleri arasında Sekonder spontan pnömotoraks_tanısıyla tedavi edilen 152 hastanın verileri retrospektif olarak değerlendirildi. Hastalar yaş, cinsiyet, mevcut akciğer hastalığı, sigara kullanımı, semptomlar, görüntüleme bulguları, lokalizasyon, pnömotoraks oranı, tedavi yöntemleri, cerrahi endikasyonlar, yatış süreleri ve mortalite oranı yönünden incelendi.

Bulgular: Yüz elli iki hastanın 128'i (\% 84.2) erkek, 24'ü (\%15.8) kadın, ortalama yaş $66 \pm 12.4$ (45-98) idi. En s1k semptomları nefes darlığı 114 (\%75), göğüs ağrısı 85 (\%55.9) ve öksürük $26(\% 17.1)$ idi. En sık komorbid hastalık kronik obstrüktif akciğer hastalığı (\%39.5) idi. Yüz on iki (\%73.7) hasta sadece tüp torakostomi ile tedavi edilirken, bunların opere edilemeyecek durumdaki 36'sına (\%32.1) tüp torakostomi yoluyla plöredezis yapıldı. Otuz bir (\%20.4) hastaya cerrahi tedavi uygulandı. Cerrahi yötemin 17'si (\%54.8) video yardımlı torakoskopi, 14'ü (\%45.2) torakotomi idi. Cerrahi endikasyonlarımızın büyük çoğunluğu uzamıș hava kaçağı ve nüks pnömotoraks idi.

Sonuç: Son yıllarda göğüs cerrahisinde cerrahi tekniklerde büyük gelişmelere rağmen SSP tedavisinde standart bir tedavi protokolü oluşturulamamıştır. Hastaların çoğunda sadece göğüs tüpü ve/veya plörodezis ile pnömotoraks tedavi edilebilecek iken, cerrahi tedavi ile morbidite ve mortalite yükselebilmektedir. Bu nedenle cerrahi tedaviden mümkün olduğunca uzak durulmalıdır.

Anahtar sözcükler: Plöredez, spontan pnömotoraks, tüp torakostomi.

\section{INTRODUCTION}

Pneumothorax that develops without any trauma is defined as spontaneous pneumothorax (SP) ${ }^{1-3}$. It is further classified into two types, i.e. primary and secondary. While there is no pathology that clinically affects the lungs in primary SP, there is an underlying lung disease in secondary SP (SSP), which is the most common cause of chronic obstructive pulmonary disease (COPD) ${ }^{1,4}$. Patients with SSP usually have a low respiratory reserve due to an underlying chronic lung disease and require urgent diagnosis and treatment due to the high mortality rate.

The purpose of this study was to evaluate the aetiology, clinical features and treatment methods for patients with SSP treated in our clinic in the light of literature data.

\section{MATERIAL AND METHODS}

The study was approved by the Local Ethics Committee (Date: 19.06.2018 / No: 209) and conducted in accordance with the principles of the Declaration of Helsinki. Data on patient files retrieved from the hospital information management system or archive were analyzed retrospectively.

We retrospectively evaluated the data of 152 patients who were treated for SSP between January 2013 - December 2017. All patients diagnosed with SSP were included in the study. The patients were examined in terms of age, gender, current lung disease, smoking, symptoms, imaging findings, localization of pneumothorax, pneumothorax rate, treatment methods, surgical indications, length of hospitalisation and mortality rate.

Chest radiography was performed for all patients. In order to determine the aetiology, chest Computerised Tomography (CT) was performed in all patients before tube thoracostomy procedure or after the lung was expanded. The extent of pneumothorax was calculated in percentage by the method defined by Kircher and Swartzel 5 . Classification was made based on pneumothorax size: partial (small or moderate pneumothorax, $<50 \%$ ) and total (large pneumothorax, $\geq 50 \%$ ). Monitoring and oxygen therapy were performed when the pneumothorax rate was $10 \%$ or less, and tube thoracostomy was performed when it was above $10 \%$. Surgery was performed for patients with prolonged air leak (more than 7-10 days) or recurrence. Video-assisted thoracoscopic surgery (VATS) and thoracotomy were performed as part of surgical treatment.

Statistical analyses were performed using SPSS software for Windows version 22.0. The numerical values were expressed as mean \pm standard deviation (mean $\pm \mathrm{SD}$ ), and categorical values were expressed as median \pm minimum maximum (median \pm min-max). The normal distribution of the parameters was evaluated by the KolmogorovSmirnov test. In the comparison of quantitative data, one-way Anova test was used for comparing parameters with normal distribution and MannWhitney U-test was used for comparison of parameters without normal distribution. Chi-square test was used for the comparison of quantitative data. $\mathrm{P}<0.05$ was considered to indicate statistical significance.

\section{RESULTS}

One hundred and twenty eight $(84.2 \%)$ of 152 patients were men, 24 were women $(15.8 \%)$ and their mean age was $66 \pm 12.4$ (45-98). The most common symptoms were dyspnoea in 114 (75\%) patients, chest pain in $85(55.9 \%)$ patients and cough in $26(17.1 \%)$ patients. The most common comorbid pathology was COPD in 60 (39.5\%) patients. Other pathologies included bullous lung disease, cancer (primary/metastatic), pneumonia, 
tuberculosis and silicosis (Table 1). Ninety-six (63.2\%) patients with SSP were smokers. Mean cigarette use was $27.4 \pm 2.28$ packs/year. Right pneumothorax was observed in $62(40.8 \%)$ patients, left in $88(57.9 \%)$ patients and bilateral in $2(1.3 \%)$ patients. Eighty six $(56.6 \%)$ patients had partial pneumothorax and $66(43.4 \%)$ patients had total pneumothorax.

Tube thoracostomy was performed in $6(40 \%)$ of 15 (9.9\%) patients who were monitored with oxygen therapy. While $112(73.7 \%)$ patients were treated with tube thoracostomy only, $36(32.1 \%)$ of them who were inoperable were treated with pleurodesis by tube thoracostomy. Among the patients who underwent pleurodesis by tube thoracostomy, autologous venous blood patch was used in 7 (19.4\%) and talc was used in $29(80.6 \%)$. Thirty one $(20.4 \%)$ patients were treated surgically, of which VATS was performed in $17(54.8 \%)$ and thoracotomy in $14(45.2 \%)$. The majority of our surgical indications were prolonged air leak and recurrent pneumothorax.

Surgical treatment modalities and details are presented in Table 2. The mean hospitalisation period of the patients treated by tube thoracostomy was $7.57 \pm 5.56$ days, while the hospitalisation period of the patients who underwent surgery was $14.2 \pm 8.58$ days. Four $(2.6 \%)$ patients experienced hospital mortality. All of them were patients who underwent tube thoracostomy ( 2 patients with lung cancer, 2 patients with COPD). There was no mortality following surgery.

Table 1: Patients' demographic datas

\begin{tabular}{|l|c|}
\hline Data & $\mathbf{n}(\boldsymbol{\%})$ \\
\hline Number of patients & 152 \\
\hline Age (years) & $66 \pm 12.4$ \\
Median & $45-98$ \\
Range & \\
\hline Gender & $128(84.2 \%)$ \\
Men & $24(15.8 \%)$ \\
Women & \\
\hline Symptoms & $114(75 \%)$ \\
Dyspnea & $85(55.9 \%)$ \\
Chest pain & $26(17.1 \%)$ \\
Cough & \\
\hline Etiologies & $60(39.5 \%)$ \\
COPD & $56(36.9 \%)$ \\
Bullous Emphysema & $18(11.8 \%)$ \\
Cancer (Primary/metastatic) & $2(1.3 \%)$ \\
Tuberculosis & $14(9.2 \%)$ \\
Pneumonia/Empyema & $2(1.3 \%)$ \\
Silicosis & \\
\hline Pneumothorax rate & $86(56.6 \%)$ \\
Partial & $66(43.4 \%)$ \\
Total & \\
\hline Laterality & $62(40.8 \%)$ \\
Right & $88(57.9 \%)$ \\
Left & $2(1.3 \%)$ \\
Bilaterally & $7.57 \pm 5.56$ \\
\hline LOS (days) & $14.2 \pm 8.58$ \\
Treatment with tube thoracostomy & $4(2.6 \%)$ \\
VATS/Thoracotomy & \\
\hline Hospital mortality & \\
\hline
\end{tabular}

VATS: Video-assisted thoracoscopic surgery, COPD: Chronic obstructive pulmonary disease, LOS: Length of stay 
Table 2: Treatment modalities in secondary spontaneous pneumothorax

\begin{tabular}{|l|c|c|}
\hline Treatment & $\mathbf{n}$ & $\boldsymbol{\%}$ \\
\hline Observation (nasal oxygen) & 9 & 5.9 \\
\hline Tube thoracostomy & 76 & 50 \\
\hline Tube thoracostomy and pleurodesis & 36 & 23.7 \\
Blood patch & 7 & 19.4 \\
Talc & 29 & 80.6 \\
\hline Surgery & 31 & 20.4 \\
Bullectomy and Pleurectomy & 18 & 58.1 \\
Bullae resection & 8 & 25.8 \\
Pleurectomy/Decortication & 5 & 16.1 \\
\hline
\end{tabular}

\section{DISCUSSION}

Spontaneous pneumothorax is a type of pneumothorax which develops without any trauma. Spontaneous pneumothorax is divided into two types, i.e. primary and secondary. Pneumothorax due to the perforation of subpleural blebs at the apex of the lung without any additional lung disease is called primary spontaneous pneumothorax (PSP) and pneumothorax due to an underlying disease in the lung is called secondary spontaneous pneumothorax (SSP). Chronic obstructive pulmonary disease with emphysema, cystic fibrosis, lung cancer, pneumocystis carinii pneumonia accompanied by HIV are the most common underlying diseases, whereas lymphangioleiomyomatosis, connective tissue diseases and histiocytosis are rarely observed ${ }^{6-9}$. Chronic obstructive pulmonary disease is the most common cause of SSP. O'Rourke ${ }^{10}$ et al. found that $22(48.9 \%)$ of 45 patients with SSP had COPD, and Weissberg and Refaely ${ }^{11}$ found that $348(68 \%)$ of 550 patients with SSP had COPD. In an SSP series of 100 cases published in Turkey, COPD ranked first with a rate of $40 \%$, while bullous lung ranked second with a rate of $25 \%{ }^{8}$.

The annual incidence of SSP is reported to be $6.3 \%$ in men and $2 \%$ in women per 100,000 people in the USA [9]. In a patient with COPD, the annual incidence of pneumothorax is approximately $26 / 100,000^{8}$. Physical examination findings of patients with COPD may not be helpful in the differential diagnosis of pneumothorax. Since these patients have limited lung capacity, respiratory distress may develop even in minimal pneumothorax. If a patient with COPD has increased respiratory distress and unilateral chest pain, pneumothorax should be considered. The majority of patients with COPD are men and smokers and generally over the age of $45^{7}$. Similarly, in the patients in our study, COPD was the most common cause with a rate of $39.5 \%$, followed by bullous lung with a rate of $36.9 \%$. Other aetiological factors found in our study included primary lung/metastatic cancer, tuberculosis, pneumonia/empyema and silicosis.

It has been reported that the most common symptoms of SSP are dyspnoea and chest pain ${ }^{8}$. Also, there may be symptoms, such as cough, bruising, fever, back pain, sweating, expectoration and weakness. In our study, dyspnoea was the most common symptom, followed by chest pain and cough.

It has been reported that the relapse rate of SSP is $40 \%-50 \%{ }^{12}$. It has been shown that adhesions are the cause of lower relapse rate of SSP than PSP. Risk factors for relapse in SSP are advanced age, lung fibrosis and emphysema ${ }^{13,14}$. In our study, 11 (7.2\%) patients had relapse.

In some publications, it was stated that pneumothorax was more common on the right, while in others there was no difference between right and left ${ }^{15}$. In our study, pneumothorax was common on the left side with a rate of $57.9 \%$.

Since the respiratory reserve is already low in patients with SSP due to underlying lung disease, the clinical picture is often severe and may be more severe than PSP. Radiological findings are fundamental in diagnosis. The visualisation of the pneumothorax line on posterior-anterior chest $\mathrm{x}$ ray is usually sufficient for diagnosis. However, especially in patients with SSP, bullae should be kept in mind in differential diagnosis. 
Computerised tomography can be used in suspected cases.

Treatment of SSP should be planned according to the general condition of the patient, the initial or recurrent pneumothorax, the size of the pneumothorax and the underlying pulmonary disease. Possible treatment options in the treatment of pneumothorax include monitoring, aspiration with catheterisation, tube thoracostomy, pleurodesis, thoracoscopy and thoracotomy. The purpose of pneumothorax treatment is to evacuate the air accumulated in the pleural space and to prevent relapse ${ }^{16}$.

Secondary spontaneous pneumothorax is more severe than clinical PSP and has a lower chance of success with simple aspiration (37\% versus $75 \%$ )

17. Therefore, patients with SSP should be hospitalised, and those who do not respond to medical treatment (nasal oxygen) should be treated with tube thoracostomy. Lung expansion should be supported by applying negative pressure to the chest tubes of patients with air leakage from the chest tube and/or those with expanded lungs.

In our study, nasal oxygen therapy was administered to 15 patients. Tube thoracostomy was performed in 6 patients who did not respond to oxygen therapy and had increased pneumothorax rate.

Pleurodesis with talc, tetracycline or autologous blood reduces the risk of relapse, especially in elderly patients with SSP who are not eligible for surgery. Chemical pleurodesis is used at the first attack or when relapse occurs in order to reduce relapses. The relapse rate of talc, which is the most effective agent in pleurodesis, has been reported to be $8 \%{ }^{18-21}$. British Thoracic Society recommends removal of the chest tube after lung re-expansion and cessation of air leak and pleurodesis in an unstoppable air leak or recurrent pneumothorax ${ }^{8}$.

In our study, talc was used in 29 patients who were not eligible for surgery for various reasons, and blood pleurodesis was performed in 7 patients.

The most common indication for surgery is prolonged air leak. Schoenenberger et al. ${ }^{22}$ reported that $34 \%$ of SSP cases required surgery due to prolonged air leak. Most clinicians advocate that surgical treatment is required if there is air leak for more than 7-10 days, whereas others state that the air leak will stop in 15 days and the surgery should not be rushed ${ }^{23}$.

In our study, the surgery rate was $20.4 \%$ (31 patients). VATS was performed in 17 (54.8\%) patients and thoracotomy was performed in 14
(45.2\%) patients. The most common indication for surgery in our study was prolonged air leak in 17 (54.8\%) patients, followed by relapse in 11 (35.5\%) patients and empyema in 3 (9.7\%) patients. Surgical methods are controversial. In their study, Freixinet et al. ${ }^{24}$ compared axillary thoracotomy and VATS and reported that there was no difference in operation time, postoperative pain, complications and hospitalisation between the two techniques, and that they observed relapse in 2 VATS patients. The presence of adhesions in SSP can make VATS process difficult. Parenchyma opening and associated air leak may occur in the stapler line used ${ }^{25}$. Besides, VATS requires single lung ventilation and poses a risk in severe pulmonary disease. The higher relapse rate in VATS is attributed to the less tissue trauma and pleural adhesion formation with this technique. Standard thoracotomy should be avoided whenever possible while performing open surgery. It has been reported that axillary thoracotomy performed with muscle sparing, minimal incision and less stretching of the ribs is a preferable surgical technique ${ }^{8}$. In our study, muscle-sparing thoracotomy was preferred in our patients who underwent thoracotomy.

The most common surgical technique used in pneumothorax is pleurectomy or apical bullae-bleb resection ${ }^{26}$. In our study, bullectomy in addition to pleurectomy was performed in 18 (58.1\%) patients, bullae resection was performed in 8 (25.8\%) patients and pleurectomy/decortication was performed in $5(16.1 \%)$ patients. No relapse was observed in any of the patients following surgery.

A complication rate of up to $30 \%$ has been reported following surgical treatment in SSP ${ }^{27}$. In our study, postoperative complications (pneumonia in 1 patient and prolonged air leak in 5 patients) were observed in $6(19.4 \%)$ patients. Pleurodesis was performed in patients with postoperative prolonged air leak. It has been reported that mortality rate may increase up to $50 \%$ in SSP. It is believed that this is due to underlying tuberculosis, lung cancer and pneumonia ${ }^{3}$. In our study, no mortality was observed following the operation. All 4 patients with mortality were those who underwent tube thoracostomy ( 2 patients with lung cancer and 2 patients with COPD).

\section{CONCLUSION}

Despite the great advances in surgical techniques in thoracic surgery in recent years, a standard treatment protocol has not been established in the treatment of SSP. While pneumothorax can be treated with only chest tube and/or pleurodesis in 
most patients, morbidity and mortality may increase with surgical treatment. Therefore, surgical treatment should be avoided as much as possible.

\section{Acknowledgments}

Consent: Written informed consent was obtained from all participants as well as from the local Ethics Commitee. (Date: 19.06.2018/209)

Conflict of Interest: No conflict of interest was declared by the authors.

Financial Disclosure: This was not an industry supported study. The authors declare that this study has received no financial support.

All authors contributed to the design and implementation of the research, to the analysis of the results and to the writing of the manuscript. All authors discussed the results and contributed to the final manuscript.

\section{REFERENCES}

1. Noppen M, Keukeleire TD. Pneumothorax. Respiration 2008;76:121-127.

2. Li Z, Huang H, Li Q, et al. Pneumothorax: observation. J Thorac Dis 2014;6:S421-S426.

3. Noppen M. Spontaneous pneumothorax: epidemiology, pathophysiology and cause. Eur Respir Rev 2010; 19: 117, 217-219.

4. Huang Y, Huang H, Li Q, et al. Approach of the treatment for pneumothorax. J Thorac Dis 2014;6:S416-S420

5. Kircher LT, Swartzel RL. Spontaneous pneumothorax and its treatment. J Am Med Assoc 1954; 155: 24-9.

6. Henry M, Arnold T, Harvey J. BTS guidelines for the management of spontaneous pnuemothorax. Thorax 2003; 58: ii39-ii52.

7. Işıtmangil $T$, Balkanlı K. Pnömotoraks ve cerrahi tedavisi. In Yüksel M, Kalaycı G, ed. Göğüs Cerrahisi; Bilmedya Grup, İstanbul, 2001: 411-45.

8. Türkyılmaz A, Erdem AF, Aydin Y, et al. Sekonder spontan pnömotoraksta tedavi: 100 olguluk tecrübe. EAJM 2007;39: 97-102

9. De Hoyos A, Fry AW. Pneumothorax. In Shields TW, LoCicero III J, Reed CE, Feins RH, ed. General Thoracic Surgery, Vol. 1, 7th ed. Philadelphia: Wolters Cluwer/Lippincott Williams and Wilkins;2009:739-61

10. Q'Rouke JP, Yee ES. Civilian spontaneous pneumothorax. Treatment options and long-term results. Chest 1989;96:1302-6
11. Weissberg D, Refaely Y. Pneumothorax: Experience With 1,199 Patients. Chest 2000;117:1279-85.

12. Videm V, Pilligram-Larsen J, Ellingsen O, et al. Spontaneous pneumothorax in chronic obstructive pulmonary disease: complications, treatment and recurrences. Eur J Respir Dis 1987;71:365-71.

13. West JB. Distribution of mechanical stress in the lung, a possible factor in localisation of pulmonary disease. Lancet 1971;1:839-41.

14. Lippert HL, Lund O, Blegvad S, et al. Independent risk factors for cumulative recurrence rate after first spontaneous pneumothorax. Eur Respir J 1991;4:324-31.

15. Güneylioğlu D, Altınsoy B, Çelik O, et al. Pnömotoraks: 174 Olgunun Değerlendirilmesi. Akciğer Arşivi. 2002;2:78-81

16. Bozkurt AK. Pnömotoraks. Solunum 2002;4: 206-9.

17. Baumann MH, Strange C: Treatment of spontaneous pneumothorax: A more aggresive approach? Chest 1997;112:789-804

18. Tschopp JM, Rami-Porta R, Noppen M, et al. Management of spontaneous pneumothorax:state of the art. Eur Respir J 2006;28:637-50.

19. Bresticker MA, Oba J, LoCicero J, et al. Optimal pleurodesis: a comparative study. Ann Thorac Surg 1993;55:364-6.

20. Colt HG, Russack V, Chiu Y, et al. A comparison of thoracoscopic talc insufflation, slurry, and mechanical abrasion pleurodesis. Chest 1997;111:442-88.

21. Massard G, Thomas P, Wihlm JM. Minimally invasive management for first and recurrent pneumothorax. Ann Thorac Surg 1998;66:592-9.

22. Schoenenberger RA, Haefeli WE, Weiss P, et al. Timing of invasive procedures in therapy for primary and secondary spontaneous pneumothorax. Arch Surg 1991;126:764-6.

23. Kuzucu A, Soysal Ö, Ulutaş H. Spontan Pnömotoraksta Rekurrens ve Cerrahi Tedavide Zamanlama. Inönü Üni Tıp Fak Der 2005;12:16972.

24. Freixinet JL, Canalís E, Juliá G, et al. Axillary thoracotomy versus videothoracoscopy for the treatment of primary spontaneous pneumothorax. Ann Thorac Surg 2004;78:417-20.

25. Oğuzkaya F, Kahraman C, Özpolat B, et al. Primer spontan pnömotoraksların tedavisinde 
video yardımlı torakoskopik cerrahi. GKD Cer Derg 1995;3:263-5.

26. Hayashida R, Hattori R. Postoperative recurrence of pneumothorax after thoracoscopic surgery: a clinical review. Jpn J Chest Dis 1996;55:352-7.
27. Sakurai H, Hada M, Miyashita $Y$, et al. Simultaneous bilateral spontaneous pneumothorax secondary to metastatic angiosarcoma of the scalp: report of a case. Surg Today 2006;36:919-22. 